\title{
Wear performance of alumina-based ceramics - a review of the influence of microstructure on erosive wear
}

\section{(Desempenho do desgaste de cerâmica à base de alumina - uma revisão dos efeitos da microestrutura no desgaste erosivo)}

\author{
P. C. Milak, ${ }^{1,2,3}$, F. D. Minatto ${ }^{1,2,3}$, A. De Noni Jr. ${ }^{1,3}$, O. R. K. Montedo ${ }^{1,2,3^{*}}$ \\ ${ }^{1}$ Programa de Pós-Graduação em Ciência e Engenharia de Materiais - PPGCEM, ${ }^{2}$ Laboratório de Cerâmica \\ Técnica, ${ }^{3}$ Grupo de Pesquisa em Cerâmica Técnica - CERTEC \\ Universidade do Extremo Sul Catarinense - UNESC, Av. Universitária 1105, P.O. Box 3167, \\ Criciúma, SC 88806-000, Brazil \\ pamela.milak@gmail.com,flavia.dagostimminatto@gmail.com,agenordenoni@gmail.com, \\ oscar.rkm@gmail.com
}

\begin{abstract}
Ceramic materials are of technical and commercial interest due to their chemical, mechanical and thermal performance, leading ceramics to meet many engineering requirements. Alumina (aluminum oxide) is one of the primary representatives of this class of materials because of its high fracture toughness, hardness and density, which enable its use in the production of highly critical parts. One such application involves protection against abrasion and erosion wear. The wear properties of a ceramic can be improved not only by controlling its material characteristics but also by controlling the fabrication process, which defines the material's microstructure. Many studies of the effects of the microstructure on these properties have been published. The objective of this study was to review the effects of the microstructure on the erosive wear resistance of alumina-based ceramics. Four factors that control the erosive wear of alumina were identified: (i) the effects of dopants on the diffusivity of the grain boundaries, (ii) the fabrication route, (iii) the sintering mechanisms and (iv) the alumina grain size. The published experimental results related to these topics are described and provide a clear understanding of the erosive wear of alumina.
\end{abstract}

Keywords: ceramics, alumina, microstructure, wear.

\section{Resumo}

Materiais cerâmicos possuem interesse técnico e comercial devido ao seu desempenho químico, mecânico e térmico, cumprindo diversos requisitos de engenharia. O óxido de alumínio (alumina) é um dos principais representantes desta classe de materiais devido, por exemplo, a sua elevada tenacidade, dureza e densidade, podendo ser aplicado na produção de peças de alta tecnologia. Uma destas aplicações envolve o emprego como material de proteção contra o desgaste abrasivo e erosivo. As propriedades em relação ao desgaste de um material cerâmico podem ser melhoradas não só levando-se em conta as características do material utilizado, mas também se deve ao processo de fabricação que define a sua microestrutura final. Inúmeros trabalhos relacionados à influência da microestrutura em suas propriedades têm sido publicados. Assim, este trabalho tem como objetivo apresentar uma revisão sobre a influência da microestrutura na resistência ao desgaste erosivo de cerâmicas a base de alumina. Quatro fatores que interferem no desgaste erosivo da alumina foram identificados: i) efeito da utilização de dopantes sobre a difusividade no contorno de grão; ii) efeito da rota de fabricação; iii) influência dos mecanismos de sinterização; e iv) influência do tamanho de grão da alumina. Os resultados experimentais relacionados aos tópicos acima são descritos e permitem uma compreensão clara sobre o desgaste erosivo de aluminas.

Palavras-chave: cerâmicas, alumina, microestrutura, desgaste.

\section{INTRODUCTION}

Ceramic materials have been used to meet many engineering requirements [1], such as in energy production and the aerospace industry $[2,3]$, because of their chemical stability and relatively high hardness [1-3], lower density compared to metals [3], high mechanical resistance $[1,3]$ and resistance to high temperatures [1-4]. Compared to other materials, ceramics are also less prone to damage caused by corrosive environments [2]. The strong interatomic ionic bonds of these oxides make it possible to obtain these properties [5].

Alumina (aluminum oxide, $\mathrm{Al}_{2} \mathrm{O}_{3}$ ) is considered to be a typical representative of engineering ceramics [1, 5-7]. Its properties are attractive in structural applications [7], automobiles, aerospace and biomedical activities and cutting 
tools [8], particularly when the environmental conditions are severe. The process of large-scale alumina production is known as the Bayer process [9, 10], which consists of its extraction from bauxite. Bauxite is dissolved in sodium hydroxide, which forms a sodium aluminate solution from which the iron oxide and silica are later separated, generating a waste called red mud. Alumina is precipitated from the sodium aluminate and calcinated to produce various alumina grades $[9,10]$. There are a large variety of commercial alumina grades, which can contain between $85 \%$ and $99.999 \% \mathrm{Al}_{2} \mathrm{O}_{3}$. This class of materials can also exhibit various densities and microstructural characteristics, such as grain size. The wear behavior of alumina may be affected by all of these variables [11].

The wear of ceramic materials is an issue of great industrial importance [1] because wear leads to the frequent replacement of components [12]. The proper selection of wear-resistant materials increases the useful life of equipment and considerably reduces maintenance costs $[1,12,13]$. Alumina is the most commonly used material in applications requiring wear resistance $[1,7,14-16]$, making this material particularly important in a wide range of applications [17]. Its various attractive properties include high chemical inertia [14], considerable fracture toughness, relatively low cost $[1,5,7,11]$, great hardness $[1-3,11,14,17]$, high erosion resistance [1-3, 16, 17], good behavior at high temperatures $[1,2,8,9,17]$, high electric resistance and great availability [8]. Many publications presented results of the effects of the microstructure of alumina on its wear behavior, and much of the focus has been on the role of grain size [18-25]. A small grain size and a narrow grain size distribution often promote increased resistance to wear [20,25]. Similar relationships between wear rates and grain sizes are observed in studies of various types of wear, such as erosion, abrasion, cutting and grinding [19].

Wear is a degradation process of a material in service and occurs because of the progressive loss of material from the contact surface or the relative movement of a solid in relation to another solid or a liquid or gas. The reason for and the mechanisms that cause wear in materials depend on the combinations of the parts involved and are approached in a more complex manner using the tribological system, which includes the damaged surface, the wear agent and the medium containing the involved parts [13]. In certain mechanisms, the hardness and fracture toughness are considered the most important properties in meeting wear requirements [26]. Abrasive wear starts with the removal of material from a surface by the movement of hard particles. The wear rate depends on the degree of abrasive penetration into the surface of the material under abrasion. Particles that cause wear usually have sharp edges to cut or shear the solid under wear. The damaged surface is under high loads because a small area is involved, thereby creating fractures in the surficial hard phases and plastic deformation of the matrix. The wear rate is affected by the properties of the wearing surface and the abrasive and the nature of the interaction between them [27]. Erosive abrasion is caused by a fluid that transports solid particles by entrainment, and these particles collide with the surface under investigation. The ASTM G 40-92 standard defines erosion as the progressive loss of a material from a solid surface due to the mechanical interaction between a surface and a fluid or a multicomponent fluid or liquid particles or impacting solids [28]. It is important to clearly differentiate between the erosion and abrasion wear mechanisms. Erosion refers to a series of solid particles colliding with a surface, whereas abrasion is the result of abrasive particles sliding across a surface due to an applied force [29]. The difference becomes clearer if one considers that in erosion, the force associated with the particles is linked to a decrease in their velocity. After the effect occurs, this velocity decreases during the entire time of contact with the surface. In abrasion, the applied force is external and is approximately constant during the process. Many industrial components are susceptible to erosive and abrasive wear. One example concerns the valves used for the production of oil associated with brine in Brazil. This use poses many technological challenges because the brine is at a depth of $7000 \mathrm{~m}$ below sea level. Due to the difficulty of accessing equipment at this depth for maintenance and the high cost involved in the replacement of piping components, oil extraction companies must use long-life valves, i.e. those with a low wear rate. A feasible alternative can be the internal plating of valves with alumina because this material exhibits high erosive wear resistance. The factors that affect the abrasive and erosive wear of alumina include the dopant contents, fabrication route, sintering mechanism and kinetics, which in turn affect the grain size and, consequently, change the microstructural properties of alumina.

\section{EFFECTS OF DOPANTS ON THE DIFFUSIVITY IN THE GRAIN BOUNDARIES}

The mechanical and microstructural properties of alumina are affected by the selection of additives [21, 30-33] and dopants [23, 34-38] used for sintering, which affect the grain size distribution and the phases formed in the grain boundaries.

Mass transfer at high temperatures and deformation by creep and densification during the sintering of fine polycrystalline $\mathrm{Al}_{2} \mathrm{O}_{3}$ grains are often controlled by diffusion of the grain boundaries. In the hot isostatic pressing diagram created by the Ashby group, the diffusion in the grain boundaries is the primary process operating in a wide range of temperatures and pressures. Creep at high temperatures and the behavior of densification are highly sensitive to low dopant levels of various cations; therefore, the diffusivity of the $\mathrm{Al}_{2} \mathrm{O}_{3}$ grain boundary is an important parameter in the production of $\mathrm{Al}_{2} \mathrm{O}_{3}$ ceramics [34]. Dopants promote sintering and reduce the mobility in the grain boundaries. $\mathrm{MgO}$, for example, has been widely used because it increases densification rates, provides a uniform grain size [39], decreases the growth rate of the grains and increases the final density of the alumina during the sintering, whereas 
dopants such as $\mathrm{SiO}_{2}$ and $\mathrm{CaO}$ are known to promote abnormal grain growth [33, 36, 40,41]. The use of rareearth dopants affects the mechanical properties, including the creep, fracture strength and wear resistance, although the mechanism that causes these property changes is unclear [37]. doping alumina with zircon and rare-earth elements $(\mathrm{Yb}, \mathrm{Gd}, \mathrm{La})$ increased the hardness of the material under sintering conditions in which the grain size was maintained below $0.5 \mu \mathrm{m}$ and a high relative density (above 97\%) was achieved [35]. To produce the doped alumina, $500 \mathrm{ppm}$ of $\mathrm{Yb}, \mathrm{Gd}$ and $\mathrm{La}$ was hot pressed at $1500^{\circ} \mathrm{C}$ onto alumina with a grain size of less than $1 \mu \mathrm{m}$; precipitates were present in the grain boundaries, which suggests the uniform saturation and segregation of the dopant [35].

The fracture behavior of the rare-earth doped alumina was one of transgranular fracturing with smaller grain sizes; intergranular fracturing increased with the inclusion of dopants due to a reduction in free surface energy resulting from the segregation of the rare-earth elements along the grain boundaries, which in turn led to intergranular flaws. Therefore, dopant segregation is not desired [35]. The use of rare-earth dopants delayed grain growth at the temperatures under investigation, and the magnitude of this delay was linked to the rare-earth species. The delay in grain growth increased with the ionic radius, i.e., in the following order: $\mathrm{Yb}<\mathrm{Gd}<\mathrm{La}$ (the smallest grain size was obtained using La). This result occurred because rareearth cations block the diffusion of $\mathrm{Al}_{2} \mathrm{O}_{3}$. However, the doped alumina displayed better intergranular fracturing behavior than the undoped material of similar grain size. In turn, transgranular fracturing increased with the reduction in grain size, caused by the intergranular microtensions of various orientations generated by thermal expansion. This effect led to spontaneous fracturing along the boundaries of larger grains [35]. Adding the rare-earth dopants did not have an enormous effect on the fracture strength; rather, the fracture strength was only modestly affected. The doped alumina exhibited greater intergranular fracturing because the dopant segregated and, thus, the cohesion along the grain boundaries decreased. However, the reduced cohesion along the grain boundaries was compensated for by the increase in the fracture surface area due to the more tortuous fracture path that was associated with the intergranular shift [35].

Doped alumina containing $0.1 \mathrm{~mol} \% \mathrm{MgO}, \mathrm{MnO}, \mathrm{SrO}$, $\mathrm{LuO}, \mathrm{TiO}_{2}, \mathrm{ZrO}_{2}$ and $\mathrm{PtO}_{2}$ was investigated during sintering at temperatures of $1300-1500^{\circ} \mathrm{C}$. The diffusivity in the $\mathrm{Al}_{2} \mathrm{O}_{3}$ grain boundary is clearly affected by the dopant cation, which segregates along the grain boundaries [34, 41]. The effect of the doping on the grain boundary diffusivity is related to the ionicity of the $\mathrm{Al}_{2} \mathrm{O}_{3}$, whereby a lower energy level of the external layers of the dopant provides a higher diffusivity for the divalent or tetravalent $\mathrm{Al}_{2} \mathrm{O}_{3}$-doping ion [34]. Diffusion along the grain boundaries dominates the alumina densification rate at grain sizes of less than $10 \mu \mathrm{m}$ [34]. $\mathrm{SrO}, \mathrm{LuO}$ and $\mathrm{ZrO}_{2}$ reduced the diffusivity in the grain boundary, whereas the other dopants improved the diffusivity behavior. In particular, $\mathrm{Mn}^{2+}$ increased the diffusivity by a factor of approximately 20 at the investigated temperatures. The segregation of cations along the grain boundaries was observed [34]. The densification in the final step is controlled by the diffusivity rate of the grain boundaries because the cation tends to segregate along the boundaries. Thus, the origin of the doping effects results in the alteration of the grain boundary diffusivity caused by the segregation of cations. The energy level of the external layer has a strong effect on the diffusivity; therefore, a lower energy level in the external layers of the dopants generates higher diffusivity in the $\mathrm{Al}_{2} \mathrm{O}_{3}$ [34]. Maiti et al. [37] used samples composed of $\mathrm{Al}_{2} \mathrm{O}_{3}+5$ wt. $\% \mathrm{ZrO}_{2}+1000$ ppm of the dopants $\mathrm{Y}$ and $\mathrm{La}$. The samples were sintered at 1500,1600 and $1700{ }^{\circ} \mathrm{C}$ for $3,6,9$ and $12 \mathrm{~h}$. The results indicated that the grain size, as in other studies [36], increased with increasing sintering temperatures [37]. The dopant $\mathrm{Y}$ inhibited grain growth, whereas La generated larger grains. The samples sintered at 1600 and $1700{ }^{\circ} \mathrm{C}$ were softer because of their larger grain sizes. The highest hardness was obtained by sintering the samples at $1500^{\circ} \mathrm{C}$. The Y- and Y-La-doped samples sintered at $1700{ }^{\circ} \mathrm{C}$ exhibited high tenacity but lower hardness and larger grain sizes [37]. The solid solubility of $\mathrm{ZrO}_{2}$ in $\mathrm{Al}_{2} \mathrm{O}_{3}$ is low, which generated a second phase. In turn, $\mathrm{Y}$ and $\mathrm{La}$ were not present in the grain boundary because they were absorbed in the formed compounds. The fracture strengths of the samples sintered at 1500 and $1600^{\circ} \mathrm{C}$ were similar [37].

In search of improvements for adaptation to industrial processes, the effect of $\mathrm{Ca}-\mathrm{Mg}-\mathrm{Si}$ dopants on the microstructures of alumina-zirconia composites was studied [36]. Several studies of zirconia were aimed at improving the properties of alumina because zirconia exhibits a higher tenacity than alumina, which improves the behavior of ceramics in wear situations. The use of $\mathrm{ZrO}_{2}$ increases the fracture strength due to the transformation of the $\mathrm{ZrO}_{2}$ tetragonal phase to the monoclinic phase, which is associated with a $3-6 \%$ increase in the specific volume. Such a volume increase causes a strain on the ceramic matrix near the $\mathrm{ZrO}_{2}-$ $\mathrm{Al}_{2} \mathrm{O}_{3}$ interface, causing difficulties in the propagation of cracks [37]. In addition, the $\mathrm{Al}_{2} \mathrm{O}_{3}+\mathrm{ZrO}_{2}$ matrix is reported to improve the densification of the material [42-44]. The first result of the study is well known [36]: higher temperatures result in larger grain sizes. In addition, greater amounts of $\mathrm{ZrO}_{2}$ result in larger $\mathrm{ZrO}_{2}$ grains and smaller alumina grains due to the drag force exerted by the $\mathrm{ZrO}_{2}$ grains on the $\mathrm{Al}_{2} \mathrm{O}_{3}$ grains [36]. The use of $\mathrm{Ca}$ and $\mathrm{Mg}$ as dopants did not significant affect the alumina grain size at temperatures below $1500{ }^{\circ} \mathrm{C}$. Between 1600 and $1650{ }^{\circ} \mathrm{C}, \mathrm{Ca}$ increased and $\mathrm{Mg}$ decreased the alumina grain size. Even at high temperatures and high calcium concentrations, which correspond to an increase in the grain size, the presence of zirconium still significantly decreased the sizes of the alumina grains. The effect of $\mathrm{ZrO}_{2}$ outweighed the effect of both dopants with a given amount of $\mathrm{ZrO}_{2}$ and dopants. The presence of $\mathrm{SiO}_{2}$ accelerated the grain growth compared to the use of $\mathrm{CaO}$ and $\mathrm{MgO}$. In turn, the use of $\mathrm{Si}$ and $\mathrm{Si}+\mathrm{Ca}$ dopants increased the alumina grain size by factors of five and three, respectively, versus materials containing only $\mathrm{Ca}$ and/or $\mathrm{Mg}$ [36]. 
The effect of $\mathrm{Nb}$ on the densification and grain growth of alumina [23] was assessed [23]. Additions of $0.1-0.5 \% \mathrm{Nb}$ were made to alumina with $99.5 \%$ purity. Sintering occurred at temperatures of $1200-1450{ }^{\circ} \mathrm{C}(2 \mathrm{~h}$ holding time $)$. The presence of $\mathrm{Nb}$ increased the densification of alumina at temperatures approximately 100 to $150{ }^{\circ} \mathrm{C}$ lower than those necessary for sintering of pure alumina. This effect was intensified as the $\mathrm{Nb}_{2} \mathrm{O}_{5}$ content increased to $0.5 \mathrm{~mol} \%$. The density of the material was $95 \%$ that of the pure alumina at $1350{ }^{\circ} \mathrm{C}$, independent of the dopant amount. The best results were obtained at sintering temperatures of 1350 to $1450{ }^{\circ} \mathrm{C}$ and using $\mathrm{Nb}_{2} \mathrm{O}$ concentrations of 0.2 to $0.5 \mathrm{~mol} \%$. A densified $\mathrm{Al}_{2} \mathrm{O}_{3}$ with a homogenous microstructure and a variety of grain sizes was obtained. The sample that was sintered at $1350{ }^{\circ} \mathrm{C}$ for $2 \mathrm{~h}$ with $0.4 \mathrm{~mol} \% \mathrm{Nb}_{2} \mathrm{O}_{5}$ attained $97 \%$ relative densification [23]. Hah et al. [38] investigated the effects of grain size and dopants on the grain boundaries in a set of alumina materials and examined the tribological behavior in a moderate wear regimen [38]. Alumina of $99.5 \%$ purity was used, $\mathrm{MgO}$ was added at a concentration of $500 \mathrm{ppm}$ to help the sintering process, and doping of the grain boundaries with $\mathrm{Y}_{2} \mathrm{O}_{3}$ at concentrations of 0 to $1500 \mathrm{ppm}$ and various grain sizes was included. Because the yttria solubility is very low, this dopant segregates to approximately $10 \mathrm{ppm}$ in the polycrystalline alumina along the grain boundaries. In this study, higher hardness resulted in smaller grain sizes, independent of the dopant concentration, and lower fracture strength. The alumina with the smallest grain size also exhibited the lowest coefficient of friction. The $\mathrm{Y}_{2} \mathrm{O}_{3}$ dopant did not significantly affect the hardness, whereas the wear resistance was proportional to the dopant concentration area in the grain boundary. Given a constant grain size, the wear resistance varied with the dopant concentration. Thus, the doping affected the hardness less than the grain size. However, a high amount of yttria dopant caused greater wear under small loads. The fracture strength was proportional to the dopant concentration in the grain boundaries. The indentation of the undoped alumina led to cracks not observed in the yttria-doped alumina. Yttria-doped alumina exhibited higher friction resistance than pure alumina. This result was related to the segregation in the grain boundaries [38].

Taking into account that the wear rate of alumina depends on the grain size [20] and that the fracture strength is affected by impurities, information regarding the average grain size and dopant concentration in the grain boundary may make it possible to establish correlations between the ceramic's mechanical, microstructural and tribological properties [38]. The observed changes in grain size and the presence of dopants in the grain boundaries cause measurable changes in the mechanical properties and the tribological behavior; however, these changes are small [38].

$\mathrm{Al}_{2} \mathrm{O}_{3}$ nanopowder containing 12 wt. $\% \mathrm{TiO}_{2}$ with average crystal sizes of $40 \mathrm{~nm}$ was used [45]. Recently, nanocrystalline materials have gained attention due to their various interesting physical properties. Nanocrystalline ceramics are used to achieve high densities without excessive grain growth [45]. Ti-doped alumina is widely used in highwear applications [46]. Wang et al. [45] prepared ultrafinegrained (UFG) ceramics. Their wear behavior was compared to that of pure alumina and coarse-grained (CG) Ti-doped alumina [45]. $\alpha-\mathrm{Al}_{2} \mathrm{O}_{3}$ and $\beta-\mathrm{Al}_{2} \mathrm{TiO}_{5}$ crystalline phases were observed, the latter resulting from the reaction between $\mathrm{Ti}$ and $\mathrm{Al}_{2} \mathrm{O}_{3}$ during the sintering process. No large differences were observed in the microstructure of the UFG and CG alumina, and both were completely densified. In general, smaller grains corresponded to $\beta-\mathrm{Al}_{2} \mathrm{TiO}_{5}$, and larger grains corresponded to $\alpha-\mathrm{Al}_{2} \mathrm{O}_{3}$. The smallest grains in the UFG alumina measured $400 \mathrm{~nm}$. The average grain size in the pure $\mathrm{Al}_{2} \mathrm{O}_{3}$ (relative density of $99 \%$ ) was $2.5 \mu \mathrm{m}$, which clearly demonstrated the feasibility of using post-metastable nanocomponents containing $\mathrm{Ti}$ solid solutions to obtain dense UFG alumina.

The Ti solute in the $\alpha-\mathrm{Al}_{2} \mathrm{O}_{3}$ was responsible for the greater hardness of the UFG alumina (17.6 GPa) relative to the CG alumina (15.3 GPa), which is consistent with studies of the effects of the solid solution composition on the material hardness [47]. Furthermore, the amount of $\beta-\mathrm{Al}_{2} \mathrm{TiO}_{5}$, which is a lower hardness crystalline phase, was lower in the UFG samples. The grain size most likely did not affect the hardness of those ceramics because the grains $(\sim 400 \mathrm{~nm})$ of the UFG alumina were too large to cause the same hardening observed in other nanomaterials [48]. Consequently, the fracture toughness of the CG alumina was slightly greater than that of the UFG alumina [45].

The wear behavior exhibited by the UFG and CG samples was typical of polycrystalline ceramics: low initial wear controlled by plastic deformation was followed by severe fracturing. The CG alumina wear was greater and more rapid than that of the UFG alumina, which correlates with the higher hardness of the UFG alumina. The UFG alumina wear was less than that of both the CG alumina and pure alumina. The transition between wear modes of the CG alumina occurred at $200 \mathrm{~min}$, whereas that of the UFG alumina was significantly delayed to $650 \mathrm{~min}$ [45].

A model of the wear behavior was presented [20]. According to this model, the controlled damage caused by plastic deformation accumulates inside the grains during the initial wear mode. This damage occurs in the form of propagating dislocations. Plasticity induces tensile stresses that move toward the grain boundaries and accumulate as a function of the wear time $t$.

Polycrystalline ceramics also display internal residual stress. Such residual stresses (RSs) arise from anisotropic thermal expansion in single-phase and non-cubic ceramics or due to the thermal expansion incompatibility of multiphase ceramics. Evaluations of the effective residual stress in two-phase ceramics, such as $\alpha-\mathrm{Al}_{2} \mathrm{O}_{3} / \beta-\mathrm{Al}_{2} \mathrm{TiO}_{5}$, can be found in the studies $[49,50]$.

Although the residual stress in the $\alpha-\mathrm{Al}_{2} \mathrm{O}_{3} / \beta-\mathrm{Al}_{2} \mathrm{TiO}_{5}$ system [45] has not been measured, the estimated value of $7.7 \mathrm{GPa}$ was found to be independent of the grain size. The necessary stress induced by the accumulated plasticity to produce a grain boundary fracture is approximately four 
times greater in the UFG alumina than in the CG alumina. Although the rates at which the stresses accumulate differed slightly among the investigated materials of various hardness values, it was clear that the degree of grain refinement has a significant beneficial effect on the wear resistance in such ceramics.

In addition to the grain size and the chemical compositions and phases in the grain boundaries [51], the grain volume and the binding force among grains should also be considered as factors determining the wear behavior [52]. The formation of a second phase along the grain boundaries may occur when alumina is densified by liquid-phase sintering [30].

Increases in the wear resistance of polycrystalline alumina due to the use of $\mathrm{SiO}_{2}$ as a dopant has been reported [53]. When observing the effects of grain size on the wear rate, the results were found to be in good agreement with others presented in the literature. The wear rate increased with increasing grain size and with decreasing $\mathrm{SiO}_{2}$ content. The wear rates were considered to be comparable to those observed in alumina-SiC nanocomposites with grain sizes similar to those of the alumina matrix. In turn, those values are higher than those observed in monolithic alumina [53].

\section{EFFECTS OF THE PROCESSING ROUTE}

There are many processing routes for producing ceramics, including slip casting, tape casting, uniaxial pressing, isopressing and extrusion [54]. The selection of a conformation and sintering method depends on many factors, such as the characteristics of the raw materials, economic considerations and the desired properties of the final product. During the conformation, for example, the particles often tend to be oriented in a preferential direction $[24,55]$, which causes this process to have a strong effect on the morphology and properties of the sintered material $[24,32,56]$, including the wear resistance. For example, the fracture toughness (non-notched) was higher in a certain

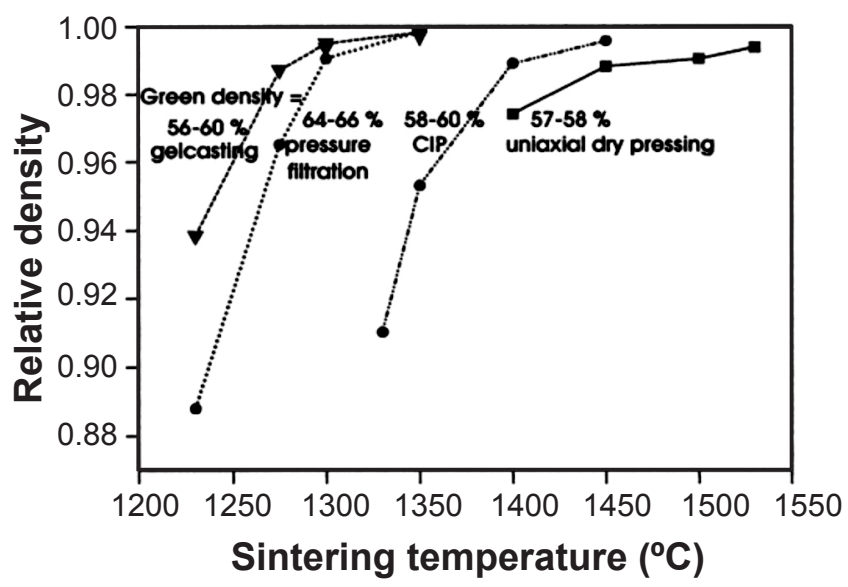

Figure 1: Influence of shaping $(\rightarrow$ homogeneity of particle coordination) on sintering [24].

[Figura 1: Influência da conformação ( $\rightarrow$ homogeneidade da coordenação da partícula) na sinterização [24].] direction in an extruded material than in a material produced by isostatic pressing [57]. In addition, the orientation of alumina plates obtained by tape casting yielded an increase of 15 to $25 \%$ in the bending strength perpendicular to the orientation of the plates [58].

The effects of various conformation methods on the sintering curves are shown in Fig. 1 [24]. The same undoped alumina of high purity ( $>99.995 \%$, Taimicron TM-DAR, Boehringer Ingelheim Chemicals Japan) and with average particle sizes of 150 to $200 \mathrm{~nm}$ was used for in all of the tests. The sintering temperatures varied by as much as $250^{\circ} \mathrm{C}$ depending on the conformation methods that were used [24].

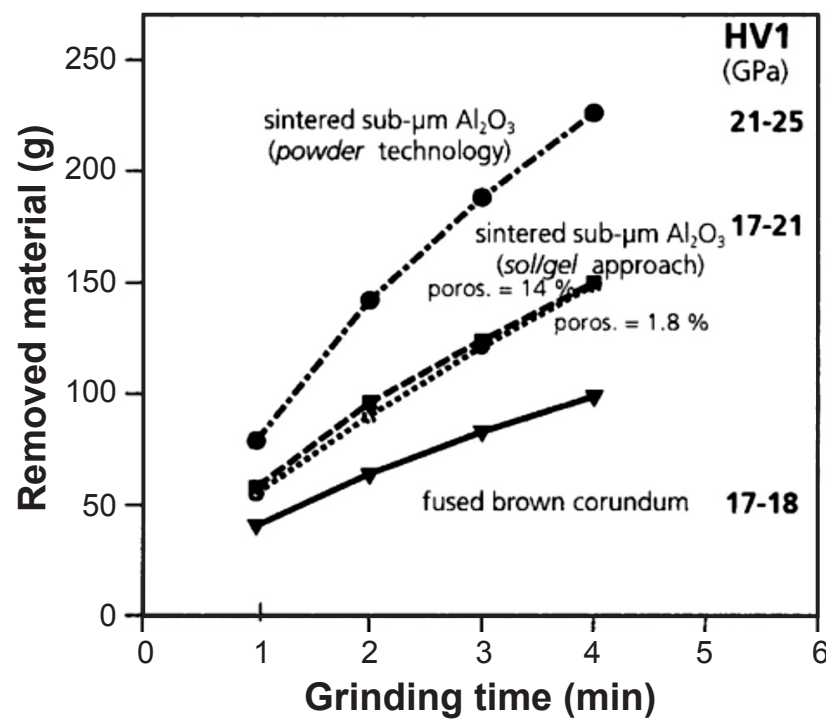

Figure 2: Use of high-purity wear-resistant submicrometer $\mathrm{Al}_{2} \mathrm{O}_{3}$ for new grinding. Grinding conditions: flexible fiber disk rotating at $6000 \mathrm{rpm}$ (contact force: $30 \mathrm{~N}$ ) abrading the cross section of a welded steel tube (wall thickness: $1 \mathrm{~mm}$; German standard ST W22/ DIN 1543) [24].

[Figura 2: Uso de alumina submicrométrica de alta pureza resistente ao desgaste para nova moagem. Condições de moagem: disco de fibra flexivel rotacionando a $6000 \mathrm{rpm}$ (força de contato: $30 \mathrm{~N}$ ) abrasionando a seção transversal de um tubo de aço soldado (espessura da parede: $1 \mathrm{~mm}$ : norma alemã ST W22/DIN 1543) [24].]

According to previous studies [59], agglomeration causes homogeneous densification to be more difficult, thereby causing variations in behavior during sintering among materials with similar green densities. The excellent performance of the TM-DAR alumina in terms of its densification was caused by the use of $200-\mathrm{nm}$ particles and the homogeneity of the green compacted particles independent of the processes used [24].

The typical ratio of powder particle size to average grain size after solid-state sintering of the alumina was shown to range between 1:4 and 1:5 [24]. It has been demonstrated that higher densification was correlated with higher ratios [24]. For example, transparent ceramics containing powder at $99 \%$ relative density and undergoing pressure filtration and sintering at $1285{ }^{\circ} \mathrm{C}$ for $2 \mathrm{~h}$ exhibited a particle size/ average grain size ratio of $1: 8$. A ratio of $1: 6$ was obtained 
using alumina at $97 \%$ relative density that was dry pressed and sintered (pressureless) at $1200{ }^{\circ} \mathrm{C}$ for $2 \mathrm{~h}$ [24]. Even with an unfavorable ratio of alumina powder to postsintering grain size, the hardness of the samples produced by pressureless sintering with a particle size of $80 \mathrm{~nm}$ was HV10 $=21-22 \mathrm{GPa}$, which is within the range of the highest values of alumina under such conditions. Using a powder with a particle size of $200 \mathrm{~nm}$ and shaping of the milling balls by fluidized bed granulation, pressureless sintering at 1300 ${ }^{\circ} \mathrm{C}$ and hot isostatic pressure during densification at $1300{ }^{\circ} \mathrm{C}$ produced a particle size/grain size ratio of 1:2, an extremely high relative density of $>99.95 \%$ and a fracture toughness of $770 \mathrm{MPa}$ [24]. It should be noted that such differences in the powder particle size/average grain size ratio are not significantly affected by the sintering conditions.

HIP certainly is a more suitable densification method for obtaining high-relative-density alumina $(>99.9 \%)$ without appreciable grain growth. Compared to microstructures at relative densities of $99-99.5 \%$, HIP generates slightly smaller grains than those obtained by pressureless sintering. For example, the finer grain sizes obtained by Krell et al. [24] using TM-DAR alumina powder doped with $0.03 \% \mathrm{MgO}$ were between 0.61 and $0.63 \mu \mathrm{m}$, with a relative density of 99.3\% after pressureless sintering, whereas HIP led to grain sizes between 0.51 and $0.57 \mu \mathrm{m}$. According to Krell et al. [24], particle homogeneity in the green bodies is the most important factor for obtaining high density submicrometric alumina, instead the use of the most refined raw powder and the sintering conditions.

The high hardness of submicrometer corundum materials enables these materials to be used to make cutting tools [60]. The sol-gel technique was commonly used to obtain materials with such characteristics, although it is currently known that this technique leads to microstructural flaws. Thus, sol-gel has been replaced by other techniques for obtaining powders [24], which produce a material with better wear characteristics, as shown in Fig. 2.

There was a lack of commercial ceramic cutting tools sufficiently strong for machining hardened steel, and diamond tools are expensive. Thus, corundum made by pressureless sintering and with a grain size of approximately $0.6 \mu \mathrm{m}$ became the perfect choice in high-speed machining environments [24].

There is a very high demand for better materials in artificial knee joints because these materials are currently made of metal and polyethylene, are prone to great wear and often need to be replaced after several years. The use of ceramics in such applications has not been satisfactory due to the high loads placed on this body part. Thus, there is great anticipation that new classes of alumina may serve in such applications: such material may exhibit the required wear resistance under high bearing loads based on technologies that combine large advances in mechanical performance without the need for complex fabrication [24].

Wet molding can be considered as a technology for the production of this material. However, there are still difficulties to be overcome regarding the high green density needed for the fluid to fill the mold as opposed to the fluid's low viscosity and due to two other important requirements: (a) the ideal powder dispersion and (b) complete mud degasification. Solutions to these problems remain limited because previous studies have approached the issue of wet conformation without considering the use of a material that starts as a fine powder [24]. According to Krell et al. [24], coarse microstructures with a powder particle size/sintered grain size ratio of 1:15 are formed when using gelcasting and starting with a corundum powder with a particle size of $0.4 \mu \mathrm{m}$ [61]. Another point that must be considered concerns the need for demolding without damaging the material. This issue is particularly challenging because of the complexity of the knee joint. Particle ordination during the drying process can be improved using organic additives [24].

When fabricating products of complex structure, such as joints, a material with low viscosity, a high solids content of refined particle size and agglutination and wet deformation ability is desired to avoid flaws during the demolding process [24].

Because of the high mechanical performance of dense submicrometer corundum [60], these materials can be used in other applications, such as in the development of armor materials. The use of high-purity submicrometer alumina with few defects can lead to transparent products that may be used in the construction, aerospace and defense industries [24]. It is clear that submicrometer alumina components with relative densities exceeding $99.7 \%$ can be produced by cold isostatic pressing or by wet molding followed by pressureless sintering [24]. The macro-hardness of these products can reach $20 \mathrm{GPa}$ with four point bending strength of $600 \mathrm{MPa}$. To obtain transparent products, wet molding and hot isostatic pressing are crucial; these processes are associated with a grain size of approximately $0.5 \mu \mathrm{m}$ and residual porosity of $0.05 \%$. This low porosity is only possible using hot isostatic pressing. The most relevant factor in producing submicrometer alumina microstructures of high relative density is the homogeneity of the green body particles obtained by wet conformation. Slip casting also favors the fabrication of products with complex shapes. Dense ceramics can be obtained using an appropriate process where it is important to avoid material agglomeration to achieve good results.

Grain sizes, fabrication routes, sintering temperatures and time and grain shapes and their orientation patterns in the microstructure were studied to evaluate the effects of those parameters on the wear performance of ceramics [32]. Coarse alumina, medium alumina and reactive alumina with grains smaller than $1 \mu \mathrm{m}$ were used. The effect of the $\mathrm{MgO} /$ $(\mathrm{CaO}+\mathrm{BaO}+\mathrm{KNaO})$ ratio in the sintering process was also evaluated. The increase in the grinding time of the alumina powders caused an increase in the relative density of the sintered material, and a density of $3.77 \mathrm{~g} / \mathrm{cm}^{3}$ was achieved after $40 \mathrm{~h}$ of grinding. This increase was not achieved with short grinding times, such as $14 \mathrm{~h}$ and $16 \mathrm{~h}$ [32]. By comparing the images of the sintered alumina samples obtained by extrusion and by uniaxial or isostatic pressing, 
it was observed that the sizes and shapes of the sintered grains can vary depending on the fabrication method [32]. In the extruded sample, a certain grain orientation was observed in the plane parallel to the extrusion direction. In addition, the materials conformed by uniaxial pressing and sintered at a high temperature $\left(1570{ }^{\circ} \mathrm{C}\right)$ displayed a microstructure of elongated grains. By increasing the temperature to $1600{ }^{\circ} \mathrm{C}$ but maintaining the same holding time of $1 \mathrm{~h}$, the grains became equiaxial and rough. This sample, designated $\mathrm{C} 2{ }_{\mathrm{S}} 14$, when conformed by tape-casting, exhibited greater grain alignment, whereas a random orientation was observed in the sample conformed by slip casting. Both conformation methods - tape casting and slip casting - resulted in significant grain growth due to the high sintering temperature and holding time [32]. The powder conformed by uniaxial pressing was assessed regarding wear due to erosion and abrasion. The 16-h grinding resulted in low wear samples, and the erosive wear did not exhibit a defined tendency. The extended grinding time did not result in significant improvements in the bending strength of the extruded samples. The $\mathrm{C} 2_{\mathrm{S}}$ powder, which was formed from one of the used coarse powders, exhibited low wear and high bending strength when the sintering temperature was maintained and the holding time was increased [32]. Based on these results, in general, the samples conformed by isostatic pressing exhibited low wear. This trend, however, is not true for all compositions, which demonstrates that the fabrication method affects the wear in different ways based on the composition. Low wear was obtained when the reactive alumina powder was shaping by isostatic pressing and liquid-phase sintering (sample $\mathrm{H} 3_{\mathrm{R}} 16$ ). The orientation of the particles after extrusion and the tape casting and slip casting processes can lead to microstructure alignment during the sintering of the material. However, a random particle orientation occurs in the compacted powder, and an isotropic microstructure is expected [32]. In that study, plate alignment was observed in the samples that underwent tape casting with equiaxial distribution.

The presence of alumina plate alignment with anisotropic growth of grains containing 5 wt. $\% \mathrm{CaO}+\mathrm{SiO}_{2}$ in a liquid medium was demonstrated [55]; elongated grains were obtained. The differences between the findings of Goswami and Das [32] and those of Seabaugh et al. [55] can be attributed to the different percentages of $\mathrm{MgO}$ used in these two studies.

When the sintering temperature varies, the shapes and sizes of the grains may also vary [32]. The grains were fine and elongated when sintered at a low temperature (approximately $1570{ }^{\circ} \mathrm{C}$ ). By increasing the sintering temperature to 1600 ${ }^{\circ} \mathrm{C}$, the grains became larger and coarser. As mentioned earlier, the morphological changes observed in the material when the sintering involved a liquid phase were caused by the processing route, the sintering temperature and time and the impurities in the grain boundaries.

The difference between the wear performance of the materials obtained by isostatic pressing and that of materials obtained by extrusion was observed in a class of samples with average particle sizes (designated $\mathrm{B} 6 \mathrm{I}_{\mathrm{I}}$ 16) [32]. As previously demonstrated [62], the removal of the material can be caused by the silicate solution in the grain boundary region, which induces microfractures due to stresses that cause grain cracking and dislocations. SEM images have shown that these grain boundary dislocations occurred in the pressed samples, although there were no fractures in the material. In addition, the extensive wear of the extruded samples may have been caused by the extensive microcracks. All of the material produced by tape casting exhibited great losses due to abrasive wear, although this material exhibited a high theoretical relative density that was nearly equal to that of the material obtained by isostatic pressing. The images of the samples produced by tape casting that were tested for wear revealed the presence of extensive microcracks. The high wear rate of the materials produced by tape casting may also be associated with the alignment of the alumina platelets parallel to the abrasion plane. On the other hand, the wear rate was lower in materials produced by extrusion due to the perpendicular orientation of the platelets relative to the abrasion plane. The material produced by slip casting showed a random orientation, which also resulted in a lower wear.

Given that the materials obtained by slip and tape casting were isothermally sintered, the effects of grain size and composition of the grain boundary may be similar. It was suggested that the wear in an aligned microstructure is likely to be controlled by the plate anisotropy of $\alpha-\mathrm{Al}_{2} \mathrm{O}_{3}$ [32]. The material obtained by uniaxial pressing displayed low wear even when its relative density was low. Based on the results associated with all the materials and their fabrication routes, it was possible to conclude that a higher density does not always result in a lower wear rate. However, the higher porosity associated with low density can cause high wear [32]. According to a previous study [16], 6.8\% porosity was a limiting value, above which the erosive wear increased rapidly. For a material to exhibit good wear performance, it is important that it have few pores because pores act as sites where material detachment begins [14].

Regarding the mechanical properties, the extruded samples and those obtained by isostatic pressing displayed intergranular fractures independent of the grain size, whereas the samples prepared by isostatic pressing also displayed transgranular fractures. According to previous studies of materials obtained from uniaxial pressing, the transgranular fractures lead to a lower hardness [63]. The lower thermal expansion coefficient of glass relative to alumina generated stresses along the grain boundaries, which contributed to the creation of transgranular fractures [63]. Thus, the residual stress along the grain boundaries caused by unknown changes in the glass may be responsible for variations in the fracture paths in the samples obtained by isostatic pressing [30].

Alumina ceramics sintered using a liquid phase produced by various conformation processes exhibited various morphologies, most likely due to the plate orientations [32]. The tape casting method produced plate orientations 
parallel to the slide plane, whereas extrusion produced alignments perpendicular to the extrusion direction. Gluing and uniaxial pressing produced random orientations. The samples produced using various fabrication paths exhibited large differences in wear loss. Higher wear was observed in the samples prepared by tape casting due to the alumina plate alignments. The extruded samples exhibited low wear possibly due to certain orientations perpendicular to the test surface. Randomly oriented platelets produced by uniaxial pressing and sliding also exhibited lower wear losses.

The sintering temperature and time also had significant effects on the grain sizes and shapes in the microstructures. Sintering over a shorter time $(1 \mathrm{~h})$ and at a lower temperature $\left(1570{ }^{\circ} \mathrm{C}\right)$ produced a microstructure with large elongated grains in a matrix of fine grains. Such large grains may be responsible for the greater fracture toughness. Based on these results, it is clear that the use of high-cost fabrication methods is not essential for the production of strong or highly wear-resistant alumina [32].

\section{EFFECTS OF LIQUID-PHASE SINTERING}

A factor of great relevance to the wear behavior of a ceramic material is the sintering mechanism and the resulting microstructural alterations. Thus, liquid-phase sintering has been increasingly used because it promotes favorable properties for severe environmental conditions [16]. Elements such as alkaline-earth silicates are commonly used as additives or sintering assistants, thereby speeding up this process by forming a reactive liquid phase [41]. The resistance to milling/grinding of liquid-phase sintered alumina can be higher than that of high-purity alumina [64]. The use of silicate additives significantly improves the wear resistance of alumina, which is also observed on an industrial scale [53].

A wide variety of liquid-phase sintered (LPS) alumina products have been used as wear-resistant material in pipes for material transportation and as components in mechanical devices. The production of materials for such applications involves controlling the chemical composition - the $\mathrm{Al}_{2} \mathrm{O}_{3}$ content, the percentages of sintering additives and the impurity level - and the process parameters and microstructures. The $\mathrm{Al}_{2} \mathrm{O}_{3}$ content in LPS materials usually ranges from 88 to $97 \mathrm{wt} . \%$, and the glass content ranges from 15 to $30 \mathrm{wt} . \%$ [30]. It has also been reported that LPS alumina can contain as much as 15 wt. $\%$ additives [16]. Liquid-phase sintering favors the formation of reaction products at considerably lower temperatures [16] than in solid-phase sintering. The kinetic parameters involved in the formation of reaction products allow for the mass transfer to be controlled by the precipitation solution process and by the phase distribution within the sintered samples [31]. The first stage of liquid-phase sintering - particle rearrangement - generally occurs at low sintering temperatures and is controlled by the viscosity and quantity of the liquid phase. Higher densification levels can be obtained using liquidphase sintering because particle rearrangement is easier and mass transfer by diffusion occurs at lower temperatures [31]. During liquid-phase sintering, the amount and viscosity of the liquid change as a function of time because the chemical composition changes. In certain cases, the $\mathrm{Al}_{2} \mathrm{O}_{3}$ is initially dissolved in the liquid, thereby contributing to the mass transfer and improving the densification. By increasing the concentration of $\mathrm{Al}_{2} \mathrm{O}_{3}$ in the liquid, even in cases when new phases do not form, the fusion viscosity may be altered.

Because of the chemical reactions that occur during the sintering, secondary crystalline phases form as reaction products, thereby causing a decrease in the amount of the liquid phase. In addition, the initial composition of the liquid phase changes, which alters the viscosity. The reaction product may delay the densification, regardless of decreasing amount of the liquid phase, which may have the same effect [31].

The difference between the variation in the thermal expansion coefficient of the glass and that of the $\mathrm{Al}_{2} \mathrm{O}_{3}$ grains may play an important role in the wear resistance of LPS materials. If the coefficient of thermal expansion of the glass grain boundary generates compressive stresses along the grain boundaries, then the material is expected to be more resistant to wear $[30,53]$. When the glass has a coefficient of thermal expansion exceeding that of alumina, then tensile stresses can be generated, resulting in a weaker grain boundary, which can favor wear. This phenomenon is observed when using $\mathrm{CaO}, \mathrm{BaO}, \mathrm{Na}_{2} \mathrm{O}$ and $\mathrm{K}_{2} \mathrm{O}$ glasses. The substitution of such glasses by $\mathrm{MgO}$ can avoid the formation of weak grain boundaries [30].

In addition to the vitreous phase in the grain boundary region, various crystalline phases can precipitate out of the liquid phase during cooling [30], and these crystals can randomly interfere in the wear process and grain growth [32]. These crystalline phases can also result in unequal thermal expansion. Thus, the crystallization process in the grain boundary region can also introduce local stresses in the boundary phase whose magnitude depends on the extension and incompatibility of the thermal expansion. The liquid phase product remains in a state of residual stress, which varies locally depending on the microstructural characteristics [30]. Surface residual stresses may occur independently of or during the cooling after sintering and thereby alter the binding forces between the grains. Therefore, these stresses can affect the wear rates of LPS materials. Such stresses can be absorbed by (i) the viscous flow of the vitreous phase at a temperature exceeding the vitreous transition temperature, (ii) plastic/elastic deformation within the phases and along the grain boundaries and (iii) microfissures [30].

LPS materials doped with intergranular magnesium silicate films may have two functions: strengthening of the grain boundaries and reduction in the rate of microcrack propagation due to the greater adhesion and the ability to absorb and dissipate energy arising from the impact between particles through plastic deformation, thereby delaying the microcracking. Despite substantiated findings, further studies on this topic are necessary [21].

Three additive groups were used to perform liquid- 
phase sintering [31]: (a) $\mathrm{SiO}_{2}$-free oxide additives, (b) additives containing $\mathrm{SiO}_{2}$ and other oxides and (c) additives containing oxides and nitrides. The sintering temperatures ranged between 1300 and $1550{ }^{\circ} \mathrm{C}$ with a holding time of 2 $\mathrm{h}$. The results suggested that ideal densification (the smallest amount of additive to obtain the highest densification) is achieved with the optimum amount of additive, which increases with the particle size of the initial powder and the sintering temperature. The liquids formed with the presence of additives composed of DyAG, YAG, AIN and $\mathrm{Si}_{3} \mathrm{~N}_{4}$ had the highest viscosity. The liquids obtained with the oxide additives containing $\mathrm{SiO}_{2}$ were classified as intermediate in viscosity, and the $\mathrm{MnO}-\mathrm{TiO}_{2}$ - and $\mathrm{FeO}-\mathrm{TiO}_{2}$-based liquids exhibited lower viscosities. The effects of certain ions on the mass transfer and grain growth during solid-phase sintering were also observed in the liquid-phase sintering. The presence of $\mathrm{Mn}^{2+}, \mathrm{Fe}^{2+}$ and $\mathrm{Ti}^{4+}$ ions contributed to grain densification and growth, whereas the $\mathrm{MgO}-, \mathrm{Cr}_{2} \mathrm{O}_{3}-$ and $\mathrm{Fe}_{2} \mathrm{O}_{3}$-based liquids delayed mass transfer along the grain boundaries [31]. Although the dissipation of the liquid phase is favored by the fusion of certain additives, such as $\mathrm{MgO}$, $\mathrm{CaO}$ and $\mathrm{Cr}_{2} \mathrm{O}_{3}$, low densification levels were obtained due to the lesser amounts of the liquid phase. This decrease occurs because the liquid phase is present during densification and solid solution is formed, thereby generating new crystalline phases in these systems, which in the majority of the cases appeared in the grain boundaries [31]. The conclusion was that for a good rearrangement in addition to low viscosity of the liquid dispersion, it is important that the additive has a high chemical affinity with $\mathrm{Al}_{2} \mathrm{O}_{3}$. The efficiency of the additives depends on the properties and quantity of the liquid phase. Additives that have a beneficial effect on sintering at low temperatures are those that melt at low temperatures with low fusion viscosities and that spread easily and contain ions that improve the mass transfer even when a secondary crystalline phase forms [31]. The most effective additives were those that caused densification until open pores were eliminated (higher than 95\%) at a lower temperature and with a smaller quantity of the additive. Thus, according to Kóstic, the most effective additives were those containing $\mathrm{SiO}_{2}$-free oxide mixtures, followed by oxide mixtures containing $\mathrm{SiO}_{2}$ and finally the mixtures of oxides and nitrides [31].

For the liquid-phase sintering of alumina using various compositions based on the $\mathrm{MgO} /\left(\mathrm{CaO}+\mathrm{BaO}+\mathrm{Na}_{2} \mathrm{O}+\mathrm{K}_{2} \mathrm{O}\right)$ ratio and $\mathrm{SiO}_{2}$, elongated grains were observed in the sintered $\mathrm{Al}_{2} \mathrm{O}_{3}$ (88-94 wt.\%) microstructure when the $\mathrm{MgO} /$ $(\mathrm{CaO}+\mathrm{BaO}+\mathrm{KNaO})$ ratio was lower than 1 and/or when the $\mathrm{SiO}_{2}$ content was outside the 4.3-5.2 wt.\% range [63, 65]. It was possible to conclude that the chemical composition of liquid-phase sintering can also play a significant role in wear performance [30]. Reports on the wear behavior of LPS alumina made from various commercial powders are still scarce. Furthermore, because a high volume of the vitreous phase is expected to form in these materials, the role of intergranular phases should be investigated, particularly under erosive and wet milling conditions.

The high wear resistance of various $\mathrm{LPS} \mathrm{Al}_{2} \mathrm{O}_{3}$ products using three types of wear tests (abrasion, erosion and wet milling) was studied [63]. There was an attempt to investigate the role of the intergranular phases and the morphology of the $\mathrm{Al}_{2} \mathrm{O}_{3}$ grains. In addition, the effects of various $\mathrm{Al}_{2} \mathrm{O}_{3}$ powders of various purity levels and particle sizes on the wear resistance were investigated. This analysis is important because of the effect of the initial particle size on the microstructure of the sintered alumina ceramics [32].

Based on an initial analysis of the presented data and the effects of grain size, the composition of the liquid phase had a great effect on the wear performance of the samples. The reactive powders (particle sizes $<1 \mu \mathrm{m}$ ) differed appreciably from the non-reactive powders (average particle size of 3.6-7.0 $\mu \mathrm{m}$ ). The morphology of the reactive powders was observed to be uniformly equiaxial, independent of the $\mathrm{MgO} /$ $\left(\mathrm{CaO}+\mathrm{BaO}+\mathrm{Na}_{2} \mathrm{O}+\mathrm{K}_{2} \mathrm{O}\right)$ ratio. However, the microstructure of the powders considered reactive but with particle sizes ranging from 2.0 to $2.25 \mu \mathrm{m}$ is very similar to that of the powders considered to be nonreactive because of the large crystallites present in the ground powder [30]. The analysis of the amount of the amorphous phase demonstrated that the grain boundaries can be crystalline when the $\mathrm{MgO} /$ $\left(\mathrm{CaO}+\mathrm{BaO}+\mathrm{Na}_{2} \mathrm{O}+\mathrm{K}_{2} \mathrm{O}\right)$ ratio is small, whereas glass may be present in the grain boundaries when the $\mathrm{MgO} /$ $\left(\mathrm{CaO}+\mathrm{BaO}+\mathrm{Na}_{2} \mathrm{O}+\mathrm{K}_{2} \mathrm{O}\right)$ ratio is large [63].

When observing the imprints in the material following the abrasive and erosive wear tests, deeper imprints were evident in the wrinkled surfaces of the samples with lower wear resistance, whereas the samples with smoother surfaces exhibited higher wear resistance. In the micrographs of the surfaces that suffered abrasion, it was possible to observe wear imprints associated with plastic deformation, microfissures that often occur along the grain boundaries and fatigue in the layers with material removal. Extensive microfissures were considered to be responsible for creating the initial wear points. The microfissure propagation and continuous wearing away of material from the surface roughens the surface. Microfissures occur along such rough surfaces due to the increase in local contacts, thereby accelerating the removal of material [30].

Based on these results [30], the wear mechanism occurring in the abrasion and erosion tests consisted of plastic deformation associated with intergranular microfractures, whereas the wear mechanism that occurred during wet milling was the dissolution of the grain boundary material and the microfractures with stress-corrosion of the fractures [62].

The wear test results of the LPS materials display large variations. The effect of grain size on the wear resistance should be analyzed before evaluating the effects of the intergranular phases. The correlation between $\mathrm{G}^{-1 / 2}$ and the wear resistance of 91-94 wt.\% LPS $\mathrm{Al}_{2} \mathrm{O}_{3}$ exhibits $\mathrm{r}^{2}$ values of 0.44 and 0.51 in the results of the abrasive and erosive tests, respectively, whereas the correlation is negligible in the results of the wet milling wear test [30]. Part of the observed differences in abrasive and erosive wear can be explained by the effect of grain size, whereas other tribo-chemical factors 
may exert a greater effect on the wear resistance in the wet milling condition [62]. Although the samples with reactive particles $(<1 \mu \mathrm{m})$ displayed better wear performance, the effects of intergranular phases should receive further study, and the good performance cannot be attributed only to grain size [30]. SEM-EDS analysis demonstrated that the $\mathrm{Al}_{2} \mathrm{O}_{3}$ content in the vitreous phase of the grain boundary of the samples produced from reactive powders is much larger than that of the samples with coarse grains $(70-100 \mu \mathrm{m})$. This result indicates the possibility of greater dissolution of $\mathrm{Al}_{2} \mathrm{O}_{3}$ in the liquid phase that formed during the sintering with the reactive powders. Another observation was that the presence of an anorthite phase in the grain boundary reduced the wear resistance of the LPS alumina [30]. The grain morphology was affected by the chemical composition of the intergranular phases in the presence of $\mathrm{Al}_{2} \mathrm{O}_{3}$ liquid-phase sintering The results [30] suggest that equiaxial morphology favors higher wear resistance. The morphology, however, may play another role. The $\mathrm{C}$-axis of elongated grains in the presence of a liquid phase may cause an increase in interfacial stresses compared to an equiaxial grain of equivalent diameter due to the anisotropy in the thermal expansion and the elasticity modulus of $\alpha-\mathrm{Al}_{2} \mathrm{O}_{3}$. However, when elongated grains are introduced to the microstructure as reinforcement material, the fracture toughness increases due to the crack deflection [66-68].

In a study, the highest toughness was attributed to the presence of reinforcement grains in the fine-grained matrix [30]. Thus, the greater wear resistance of certain samples than others can be explained by the higher toughness, which is a result of the increase in the average grain size [69].

The beneficial effects of magnesium and calcium silicate additions on the wear resistance of alumina materials were demonstrated. However, the mechanism of action of the silicates was not determined, and many models have been suggested. Therefore, the effect of up to $10 \mathrm{wt} . \%$ magnesium silicate (stoichiometry $1: 1\left[\mathrm{MgSiO}_{3}\right]$ ) on completely dense polycrystalline alumina was studied, including analyses of the effects of the amount of additive and the average grain size and correlation of this data with the wear rate [21]. The strong effect of the alumina grain size on the wear rate was confirmed. The incorporation of magnesium silicate sharply decreased the wear rate of the alumina. The wear rate of pure alumina with an average grain size of $2.5 \mu \mathrm{m}$ under standard conditions was $33 \pm 3 \mathrm{~nm} / \mathrm{s}$; the addition of 0.5 wt. $\% \mathrm{MgSiO}_{3}$ decreased the wear rate to $18.1 \pm 0.4$ $\mathrm{nm} / \mathrm{s}$. Further increases in the silicate content resulted in additional reductions, and the wear rate appeared to reach a minimum, i.e., approximately $10 \mathrm{~nm} / \mathrm{s}$, with the addition of approximately $10 \mathrm{wt} . \%$ magnesium silicate [21], as shown in Fig. 3.

Fig. 4 shows the polycrystalline alumina wear rates with and without magnesium silicate as a function of the average alumina grain size. The wear rates of all these materials increased with the average grain size of the alumina. The wear rates of all the materials also increased with the sintering holding time and with the consequent increase in the grain

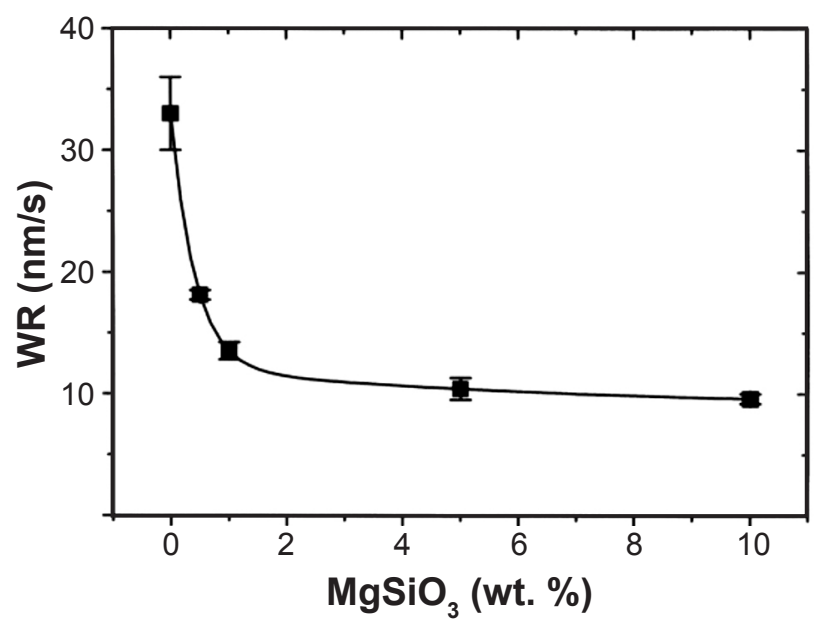

Figure 3: The wear rate of polycrystalline aluminas with different magnesium silicate contents [21].

[Figura 3: Taxa de desgaste de aluminas policristalinas com diferentes teores de silicato de magnésio [21].]

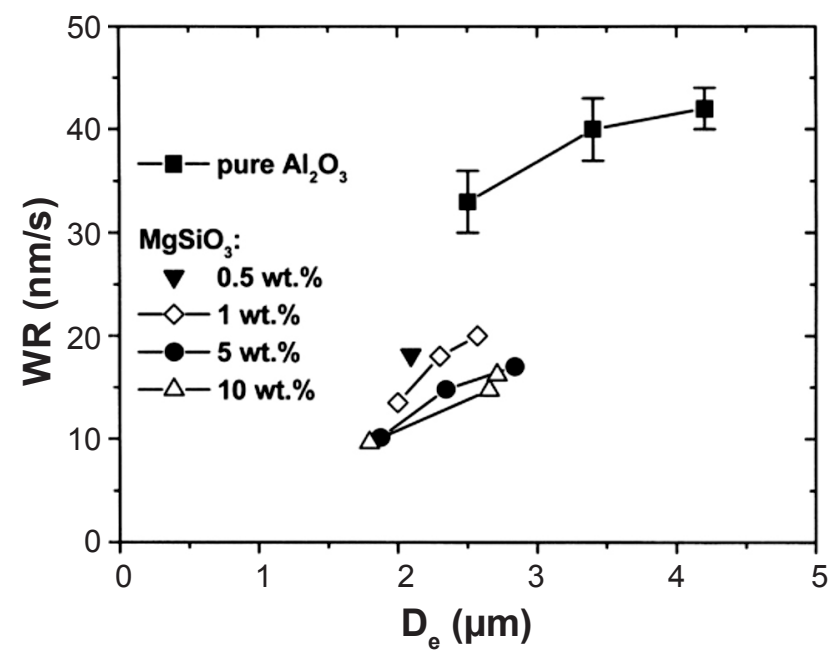

Figure 4: The wear rate of polycrystalline aluminas with different magnesium silicate content as a function of the mean grain size [21]. [Figura 4: Taxa de desgaste de aluminas policristalinas com diferentes teores de silicato de magnésio como uma função do tamanho médio de grão [21].]

size. Nevertheless, the wear rates of LPS alumina remained between 50 and $30 \%$ of the wear rate of pure alumina of comparable grain sizes [21]. Another important finding was that magnesium silicate inhibited the grain growth, thereby providing a more uniform grain size distribution.

\section{EFFECTS OF GRAIN SIZE}

The role of the grain size of alumina in wear behavior has been widely studied [18-25] and has prompted considerable improvements in these materials. The grain size of the sintered material is already considered to be the primary factor controlling the wear resistance [20, 21, 23, 70].

The mechanical properties of alumina are strongly affected by its grain size. When comparing materials of the same composition, improvements are observed in 
those of finer grain sizes. The transition from "moderate wear" to "severe wear" occurs as microfissuring becomes more rapid and the grain size increases. Thus, fine-grained ceramics are used in practical applications due to their excellent mechanical [23], electrical [23] and optical [23, 71] properties. Grain refinement is the most likely cause of the delay in the wear transition time, which results in the improved wear resistance of ceramics. Below a certain grain size (nanoceramics), the effects of plasticity on the size tend to become important, resulting in greater hardness [48]. The mechanical resistance, dielectric properties and transparence are strongly affected by the microstructure of the alumina ceramics and by the porosity and the grain size distribution [23]. By controlling the microstructure to achieve fine-grained, dense ceramics, it is possible to improve alumina's properties for various applications. The mechanical resistance of alumina can be improved by decreasing the grain dimensions and achieving a residual porosity of less than $0.05 \%$ [24]. Structural ceramics with coarse grains exhibit greater erosive wear than those with fine grains [3]. A study of the erosive wear of LPS alumina demonstrated that the erosion rate appears to be controlled by a set of factors, a few of which are related to the grain size [21].

With the increasing availability of commercial alumina powders of nanometric size, materials with submicrometric grain sizes have been successfully manufactured; these products exhibit high wear resistance [72], hardness [60], strength [73] and, generally, high toughness. Such favorable properties make fine-grained alumina an attractive material for applications where a high resistance to loads and wear is required, such as pumps, seals, high precision hoses and biomedical implants [22].

Below a certain grain size - i.e., in nanoceramics - the effects of plasticity on the size tend to become important and result in greater hardness [25]. Hence, the combination of greater hardness and nanometer-scale flaws along grain boundaries can result in the improved wear resistance of nanoceramics.

Based on an evaluation of the alumina properties at various grain sizes, the density and hardness increased with smaller grain sizes [22], as shown in Table I. In that study, the wear rate decreased with reductions in the alumina grain size, as shown in Fig. 5.

Micrographs of worn samples demonstrated that the compacting of remains from sliding surface wear that

Table I - Properties of alumina as a function of grain size [22].

[Tabela I-Propriedades da alumina em função do tamanho de grão [22].

\begin{tabular}{lccc}
\hline Grain size & $4.0 \mu \mathrm{m}$ & $0.95 \mu \mathrm{m}$ & $0.45 \mu \mathrm{m}$ \\
\hline Density $\left(\mathrm{g} / \mathrm{cm}^{3}\right)$ & 3.94 & 3.92 & 3.96 \\
Vickers hardness $(\mathrm{GPa})$ & 17.5 & 20.56 & 23.77 \\
Indentation toughness & 3.21 & 3.25 & 3.28 \\
$\left(\mathrm{MPa} / \mathrm{m}^{2}\right)$ & & & \\
\hline
\end{tabular}

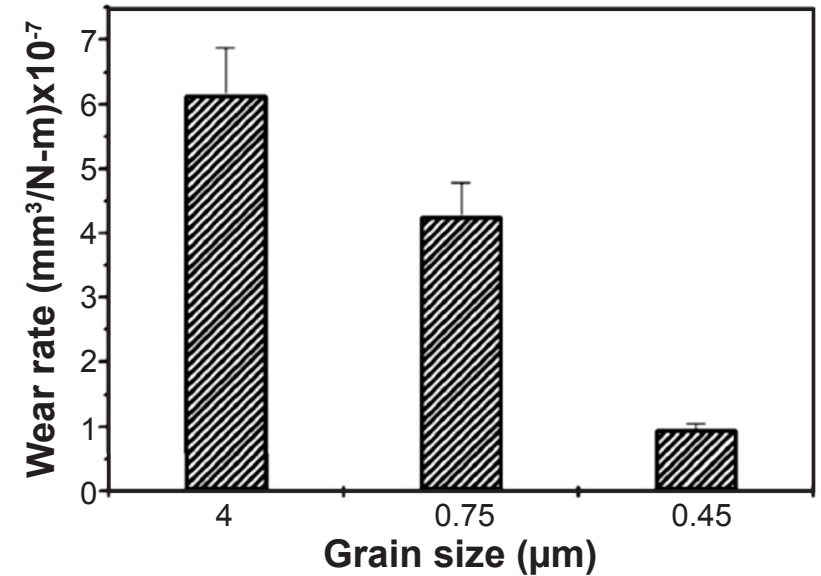

Figure 5: Average wear factor of various alumina used [22].

[Figura 5: Fator médio de desgaste de várias aluminas empregadas [22].]

occurs in sub-micrometric alumina may favor the results shown in Fig. 5 [22].

The effects of composition and microstructure on abrasive wear of a series of alumina ceramics with purity levels of 85 to $99.997 \%$ indicated that to improve wear resistance, the alumina grain size should be small, independent of the alumina content [11].

However, controversially, certain observations suggest that wear increases with grain size increasing, from a given grain size. It is suggested that the effect of grain size on the wear behavior of alumina is strongly affected by the geometry of the contact [69]. An increase in wear resistance can also be obtained by introducing large elongated grains as reinforcement in the microstructure, which improves the fracture toughness of the composite [69]. Improvements in the wear behavior, both erosive and abrasive, may be obtained with the use of reactive particles (smaller than $1 \mu \mathrm{m}$ ); however, such improvement cannot be attributed only to grain size, making it necessary to evaluate the role of intergranular phases $[30,51,52]$. In addition, with the presence of very small grains $(<100 \mathrm{~nm})$, certain mechanical properties deteriorate [74] or are not improved [75] due to the effect of the increase in grain boundaries on deformation.

In a study in which alumina was sintered using a liquid phase, there was no significant difference between the wear resistance of average and coarse-grained powders [30]. A statistical test ( $\mathrm{Z}$ test) on the abrasion resistance data obtained from coarse $(70-100 \mu \mathrm{m})$ and average $(3.6-7.0 \mu \mathrm{m})$ powders of $\mathrm{Al}_{2} \mathrm{O}_{3}$ demonstrated that the difference in wear resistance was not significant. This result suggests that various coarse $\mathrm{Al}_{2} \mathrm{O}_{3}$ powders can be used in ordinary applications and that various powders of average size can be used as wearresistant materials for commercial applications, such as wet milling [30].

The strong dependency of the wear rate on the alumina grain size was demonstrated [18]. Fig. 6 shows the behavior of alumina when undergoing erosive wear, with grain sizes ranging between 1 and $15 \mu \mathrm{m}$. The wear rates increase with increasing grain size [18]. 


\section{MISCELLANEOUS}

The use of nanostructures to improve mechanical behavior requires special processing conditions, and technical progress in the improvement of material properties appears to be closer with the use of sintered materials with submicrometric particles than with nanometric microstructures [24]. In another study using nanoparticles, the addition of up to $10 \mathrm{vol} . \%$ of $\mathrm{SiC}$ nanoparticles increased the wear resistance of polycrystalline alumina [21].

To obtain a dense microstructure of submicrometric grain size, the process must begin with a powder of even smaller size, and it is important to consider that this small

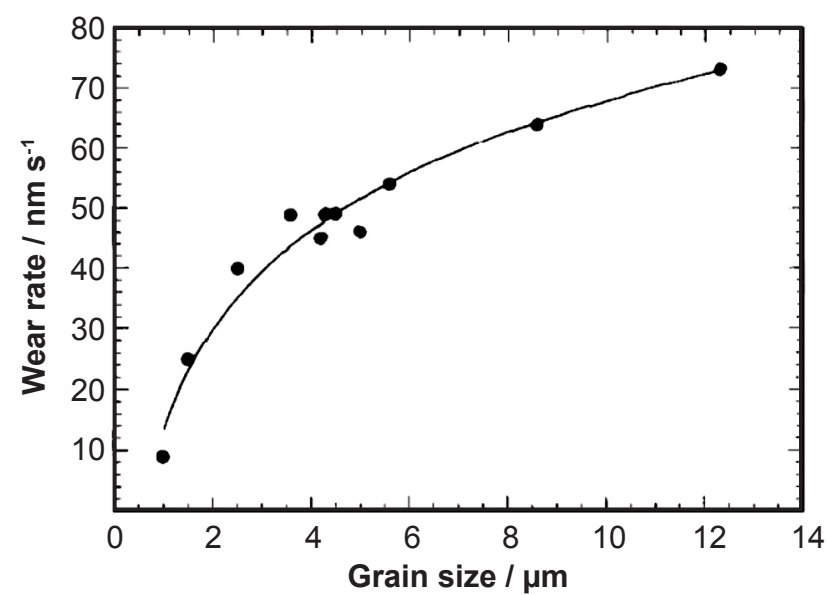

Figure 6: Wear rate-grain size dependence in the wet erosive wear of pure polycrystalline alumina [18].

[Figura 6: Dependência da taxa de desgaste-tamanho de grão no desgaste erosivo a úmido de alumina policristalina pura [18].]

size will generate high retraction during the sintering. Thus, a process that avoids flaws may be the primary requirement for the industrial production of the submicrometric material. This requirement is important for improving the mechanical properties and becomes even more essential when improving the optical properties [24]. For example, to obtain great hardness in sintered corundum of submicrometric particles, the residual porosity must be between 0.3 and $0.5 \%$ [76]. To achieve high light transmission, however, the porosity must be reduced to less than $0.05 \%$ [71].

To obtain alumina powder of reduced particle size without contamination, it is beneficial to use high-purity alumina balls. The use of zirconia spheres even in small concentrations, i.e., less than $1 \%$, may delay the densification. It is possible to obtain alumina powder with a purity of $>99.99 \%$, which results in increased corrosion resistance and decreased crack growth in the sintered products [24]. Furthermore, transparent products can be obtained.

It was attempted to correlate experimental wear rates with those predicted using equations of standard wear rates, i.e., to relate the wear rate with fracture toughness and hardness [21]. However, no correlation was observed.

Certain studies investigated the use of coatings to improve the abrasion and erosion resistance of materials, not necessarily alumina. There are several criteria for improving such properties of many types of materials. The following microstructural characteristics exert great effects on the wear resistance of a coating: (a) the size, shape and distribution of the precipitate in the hard phase, (b) the content and volume of the hard phase, and (c) the hardness of the microstructural constituents and their properties and texture [13].

Novel dense alumina-mullite ceramics have been studied. These materials include alumina-based material with appreciable mullite content and alumina-based materials containing mullite, zirconium and zircon. Both types of materials have a uniform microstructure of high crystallinity, noteworthy physical properties, high ballistics performance and high wear resistance; the latter two are considered to be function of the phase composition and the microstructure of the ceramics [7].

One method to improve the properties of alumina ceramics is to create a secondary crystalline phase $[4,7,77]$, which can increase the fracture strength and improve the wear resistance. Alumina composites have been studied with the goal of improving their wear resistance [14]. Alumina composites with the addition of $10 \mathrm{vol} . \%$ alumina titanate of small grain size $(<2.2 \mu \mathrm{m})$ and homogeneous distribution yielded a significant increase in the wear resistance [14]. Similarly, the presence of the mullite phase in alumina ceramics might have a positive effect on the ceramic properties if the amount of $\mathrm{Al}_{2} \mathrm{O}_{3}$ does not exceed $98 \mathrm{wt} . \%$ $[7,78]$.

The wear resistance of the alumina/mullite composites was two to three times higher than that of monolithic alumina. The primary explanation for this increase is the reduction in the area fraction removed from the worn surface with the change in the fracture mode, which passed from brittle (monolithic alumina) to controlled fracturing with a plastic mechanism (alumina/mullite composite) [78].

Given that the coefficient of thermal expansion of alumina is higher than that of mullite, the state of residual stress in the alumina/mullite composite is such that the particles of the second phase are in hydrostatic compression, and there are tensile stresses at the interfaces between the particles and the surrounding matrix. Thus, the cracks in the composites propagate by following pathways between the particles, which leads to weakened grains in the matrix. In turn, the contrary compressive stresses of the particles can be passed to the grain boundaries, reinforcing them. According to the results obtained by Luo et al. [78], the weakening and reinforcement effects of intergranular residual stresses along the grains and grain boundaries increase with the amount of the second phase. When the force on the grain boundaries nearly equals the force in the grains, transgranular fracturing dominates [79].

Silicon carbide can also be used as a second phase by its inclusion in alumina composites to improve the wear properties of the material [4]. The wear resistance of the alumina-SiC composites and alumina-mullite composites was two to four times higher than that of monolithic alumina, which is consistent with other findings [78]. 
The wear resistance of the composites was the result of the combination of the fracture mode and mechanical properties. The primary explanation for the better wear resistance of these composites is the transition of the fracture mode, which changed from an intergranular to a transgranular fracture mode $[4,80]$.

Advanced ceramics and ceramics containing carbon composites and nanocomposites, such as $\mathrm{SiC}$ [81-83], exhibit excellent properties. Nevertheless, three problems should be addressed when using these composites: the dispersion of the carbon nanotubes in the matrix, the densification of the composites and the degradation of carbon nanotubes, which is caused by the long milling times needed to form the mixture containing the matrix [5]. The composite exhibited lower hardness than the monolithic material due to the presence of residual porosity, which remained in the material after it was sintered [5]. Agglomeration of the nanotubes also occurred due to flaws in the processing, which confirms the difficulty of preparing such composites.

As was previously explained, the grain size is a crucial factor controlling the wear properties of pure alumina. However, the grain size does not have the same significance in alumina-SiC nanocomposites [81, 82].

The greater wear resistance of the alumina-SiC nanocomposites occurs because the presence of $\mathrm{SiC}$ reduces the fraction of material removed during severe wear through the alteration of the intergranular fracture mode in $\mathrm{Al}_{2} \mathrm{O}_{3}$ to the transgranular mode in $\mathrm{Al}_{2} \mathrm{O}_{3}-\mathrm{SiC}$ nanocomposites. This transgranular fracture mode produces a smoother surface that undergoes less wear $[80,81]$. The addition of only 2 vol.\% $\mathrm{SiC}$ is sufficient to cause a change in the fracture mode [81].

\section{CONCLUSIONS}

Grain refinement is the most likely cause of the delay in wear transition time and the consequent improvement in the wear resistance of ceramics. The pattern of behavior exhibited by ceramics is "smaller is better", whereby smaller grain sizes favor better properties of this class of materials. Based on the factors presented, alumina has been judged as the ceramic material that, considering economic matters and its high engineering performance, confers the best properties on the corresponding microstructure. Proper conformation followed by a suitable heat treatment may produce a product with high wear resistance. As discussed, the grain size exerts a high degree of control on the wear resistance of alumina and must be considered when the goal is to optimize this property, although there are outlier data indicating that the understanding of the wear mechanisms of alumina of submicrometric grain sizes is still far from complete. It is important to emphasize that the topics studied in this article affect the grain size in various ways depending on the alumina composition. It is not possible to standardize a process for a certain alumina content that will ensure a final product with high wear performance. However, based on this review, it is possible to select efficient methods to improve the microstructure and final properties of a material produced from alumina powder. The following fundamental conclusions can be drawn from this study: - the grain size has the greatest effect on the material's wear resistance; starting with powders of nanometric size can often diminish wear due to the interference of grain boundaries; - the use of dopants may or may not favor grain growth depending on the type of dopant used. However, the improvement in wear resistance using dopants cannot be associated only with the grain size, making it necessary to study the formation of intergranular phases; - the fabrication route of a product has a strong effect on the material's wear behavior, and it is necessary to consider the alignment of grains during the conformation process, which often causes greater interference than the sintering process; - the liquid-phase sintering of alumina can serve as an alternative for inhibiting excessive grain growth; however, this process should receive additional study; - compressive stresses in liquidphase sintered alumina particles result in their improved wear resistance.

\section{ACKNOWLEDGMENTS}

The authors would like to thank FINEP - Financiadora de Estudos e Projetos and $\mathrm{CNPq}$ - Conselho Nacional de Desenvolvimento Científico e Tecnológico, for the support given to this project.

\section{REFERENCES}

[1] E. Medvedovski, "Wear-resistant engineering ceramics", Wear 249 (2001) 821-828.

[2] J. Zhou, S. Bahadur, "Erosion characteristics of alumina ceramics at high temperatures", Wear 181-183 (1995) 178188.

[3] Y. Zhang, Y. B. Cheng, S. Lathabai, "Erosion of alumina ceramics by air- and water-suspended garnet particles" Wear 240 (2000) 40-51.

[4] F. C. Zhang, H. H. Luo, T. S. Wang, S. G. Roberts, R. I. Todd, "Influence factors on wear resistance of two alumina matrix composites, Wear 265 (2008) 27-33.

[5] V. Puchy, P. Hvizdos, J. Dusza, F. Kovac, F. Inam, M. J. Reece, "Wear resistance of $\mathrm{Al}_{2} \mathrm{O}_{3}-\mathrm{CNT}$ ceramic nano composites at room and high temperatures", Ceram. Int. 39 (2013) 5821-5826.

[6] F. Cesari, L. Esposito, F. M. Furgiuele, C. Maletta, A. Tucci, "Fracture toughness of alumina-zirconia composites", Ceram. Int. 32 (2006) 249-255.

[7] E. Medvedovski, "Alumina-mullite ceramics for structural applications", Ceram. Int. 32 (2006) 369-375.

[8] A. S. Kumar, A. R. Durai, T. Sornakumar, "Wear behaviour of alumina-based ceramic cutting tools on machining steels", Trib. Int. 39 (2006) 191-197.

[9] N.-K. Park, H.-Y. Choi, D.-H. Kim, T. J. Lee, M. Kang, W. G. Lee, H. D. Kim, J. W. Park, "Purification of $\mathrm{Al}(\mathrm{OH})_{3}$ synthesized by Bayer process for preparation of high purity alumina as sapphire raw material”, J. Cryst. Growth $\mathbf{3 7 3}$ 
(2013) 88-91.

[10] A. R. Hind, S. K. Bhargava, S. C. Grocott, "The surface chemistry of Bayer process solids: a review", Colloids Surf. 146 (1999) 359-374.

[11] C. P. Doğan, J. A. Hawk, "Role of composition and microstructure in the abrasive wear of high-alumina ceramics", Wear 225-229 (1999) 1050-1058.

[12] Y. Sahin, O. Durak, "Abrasive wear behaviour of austempered ductile iron", Mater. Des. 28 (2007) 18441850.

[13] T. Hejwowski, "Erosive and abrasive wear resistance of overlay coatings", Vacuum 83 (2009) 166-170.

[14] C. Baudín, A. Tricoteaux, H. Joire, "Improved resistance of alumina to mild wear by aluminium titanate additions", J. Eur. Ceram. Soc. 34 (2014) 69-80.

[15] L. Esposito, A. Tucci, "Microstructural dependence of friction and wear behaviours in low purity alumina ceramics", Wear 205 (1997) 88-96.

[16] B. A. Latella, B. H. O'Connor, "Effect of porosity on the erosive wear of liquid-phase-sintered alumina ceramics", J. Am. Ceram. Soc. 82, 8 (1999) 2145-2149.

[17] L. Ćurković, I. Kumić, K. Grilec, "Solid particle erosion behaviour of high purity alumina ceramics", Ceram. Int. 37 (2011) 29-35.

[18] R. W Davidge, F. L Riley, "Grain-size dependence of the wear of alumina", Wear 186-187 (1995) 45-49.

[19] M. M. Martinez, R. W. Davidge, F. L. Riley. "Grain size effects on the wet erosive wear of high-purity polycrystalline alumina", Wear 172 (1994) 41-48.

[20] S.-J Cho, B. J Hockey, B. R. Lawn, S. J. Benninson, "Grain-size and $R$-curve effects in the abrasive wear of alumina" J. Am. Ceram. Soc. 72 (1989)1249-1252.

[21] D. Galusek, P. C. Twigg, F. L. Riley, "Wet erosion of liquid phase sintered alumina", Wear 233-235 (1999) 588595.

[22] R. S. Roy, H. Guchhait, A. Chanda, D. Basu, M. K. Mitra. "Improved sliding wear-resistance of alumina with sub-micron grain size: A comparison with coarser grained material", J. Eur. Ceram. Soc. 27 (2007) 4737-4743.

[23] Y. F. Hsu, S. F. Wang, Y. R. Wang, S. C. Chen, "Effect of niobium doping on the densification and grain growth in alumina", Ceram. Int. 34 (2008) 1183-1187.

[24] A. Krell, P. Blank, H. Ma, T. Hutzler, M. Nebelung, "Processing of high-density submicrometer $\mathrm{Al}_{2} \mathrm{O}_{3}$ for new applications", J. Am. Ceram. Soc. 86 (2003) 546-553.

[25] A. K. Mukhopadhyay, Y. W. Mai, "Grain size effect on abrasive wear mechanisms in alumina ceramics", Wear 162164 (1993) 258-268.

[26] A. Ball, "The mechanisms of wear and the performance of engineering materials", J. South Afr. Inst. Min. Metall., 86, 1 (1986) 1-13.

[27] X. Dong, S. Jahanmir, S. M. Hsu, "Tribological characteristics of $\alpha$-alumina at elevated temperatures", J. Am. Ceram. Soc. 74, 5 (1991) 1036-1044.

[28] C. M. Marques, Relação entre microestrutura e desgaste erosivo a frio e a quente em materiais cerâmicos à base de alumina [Relationship between microstructure and cold and hot erosive wear in alumina-based ceramics materials], Thesis (Dr. Eng.), Univ. Fed. Rio Grande do Sul, Porto Alegre, RS, Brazil (2006) 1-170.

[29] L. A. Novelli, Contribuição aos estudos dos mecanismos de interação das partículas abrasivas com as microestruturas de ferros fundidos em processo de desgaste [Contribution to the studies on mechanisms of interaction between the abrasive particles and the cast-iron microstructures in the wear process], Diss. Mestrado (M.Sc. Mater. Eng.), Rede Tem. Eng. Mater., UFOP-CETEC-UEMG, Ouro Preto, MG, Brazil (2004) 1-101.

[30] A. P. Goswami, S. Roy, M. K. Mitra, G. C. Das, "Influence of powder, chemistry and intergranular phases on the wear resistance of liquid-phase-sintered $\mathrm{Al}_{2} \mathrm{O}_{3}$ ", Wear 244 (2000) 1-14.

[31] E. Kostić, S. Bošković, S. J. Kiss, "Reaction sintering of $\mathrm{Al}_{2} \mathrm{O}_{3}$ in the presence of the liquid phase", Ceram. Int. 19 (1993) 235-240.

[32] A. P. Goswami, G. C. Das, "Role of fabrication route and sintering on wear and mechanical properties of liquidphase-sintered alumina", Ceram. Int. 26 (2000) 807-819.

[33] W. A. Kaysser, M. Sprissler, C. A. Handwerker, J. E. Bluedell, "Effect of a liquid phase on morphology of grain growth in alumina", J. Am. Ceram. Soc. 70, 5 (1987) 339343.

[34] H. Yoshida, S. Hashimoto, T. Yamamoto, "Dopant effect on grain boundary diffusivity in polycrystalline alumina", Acta Mater. 53 (2005) 433-440.

[35] G. D. West, J. M. Perkins, M. H. Lewis, "The effect of rare earth dopants on grain boundary cohesion in alumina", J. Eur. Ceram. Soc. 27 (1918) 1913-1918.

[36] K. Biotteau-Deheuvels, L. Zych, L. Gremillard, J. Chevalier, "Effects of Ca-Mg- and Si-doping on microstructures of alumina-zirconia composites", J. Eur. Ceram. Soc. 32 (2012) 2711-2721.

[37] K. Maiti, A. Sil, "Microstructural relationship with fracture toughness of undoped and rare earths $(\mathrm{Y}, \mathrm{La})$ doped $\mathrm{Al}_{2} \mathrm{O}_{3}-\mathrm{ZrO}_{2}$ ceramic composites", Ceram. Int. 37 (2011) 2411-2421.

[38] S. R. Hah, T. E. Fischer, P. Gruffel, C. Carry, "Effect of grain boundary dopants and mean grain size on tribomechanical behavior of highly purified $\alpha$-alumina in the mild wear regime", Wear 181-183 (1995) 165-177.

[39] Il-J. Bae, S. Baik, "Abnormal Grain Growth of Alumina", J. Am. Ceram. Soc. 80 (5) (1997) 1149-56.

[40] C. A. Handwerker, P. A Morris, R. L. Coble, "Effects of chemical inhomogenities on grain growth and microstructure in alumina", J. Am. Ceram. Soc. 72, 1 (1989) 130-136.

[41] H. Song, R. L. Coble, "Origin and growth kinetics of plate-like abnormal grains in liquid-phase-sintered alumina", J. Am. Ceram. Soc. 73, 7 (1990) 2077-2085.

[42] J. M. Calderón-Moreno, A. R. Arellano-López, A. Domínguez-Rodríguez, J. L Routbort, "Microstructure and creep properties of alumina/zirconia ceramics", J. Eur. Ceram. Soc. 15 (1995) 983-988.

[43] C. Wang, C. Huang, Y. Wu, "Two-step sintering of fiTw alumina-zirconia ceramics", Ceram. Int. 35 (2009) 1476- 
1472.

[44] W. Tuan, J. Chen, C. Ho, "Critical zirconia amount to enhance the strength of alumina", Ceram. Int. 34 (2008) 2129-2135.

[45] X. Wang, N. P. Padture, H. Tanaka, A. Ortiz, "Wearresistant ultra-fine-grained ceramics", Acta Mater. 53 (2005) 271-277.

[46] P. Bansal, N. P. Padture, A. Vasiliev, "Improved interfacial mechanical properties of $\mathrm{Al}_{2} \mathrm{O}_{3}-13 \mathrm{wt} \% \mathrm{TiO}_{2}$ plasma-sprayed coatings derived from nanocrystalline powders", Acta Mater. 51 (2003) 2959-2970.

[47] T. E. Mitchell, A. H. Heuer, "Solution hardening by aliovalent cations in ionic crystal", Mater. Sci. Eng. 28 (1977) 81-97.

[48] H. Gleiter, "Nanostructured materials: basic concepts and microstructure", Acta. Mater. 48 (2000) 1-29.

49. B. R. Lawn, N. P. Padture, L. M. Braun, S. J. Bennison, "Model for toughness curves in two-phase ceramics: I, basic fracture mechanics", J. Am. Ceram. Soc. 76, 9 (1993) 22352240.

[50] N. P. Padture, J. L. Runyan, S. J. Bennison, L. M. Braun, B. R. Lawn, "Model for toughness curves in two-phase ceramics: II, microstructural variables", J. Am. Ceram. Soc. 76, 9 (1993) 2241-2247.

[51] C. P. Doğan, J. A. Hawk, "Effect of grain boundary glass composition and devitrification on the abrasive wear of $\mathrm{Al}_{2} \mathrm{O}_{3}$ ", Wear 181-183 (1995) 129-137.

[52] O. O. Ajayi, K. C. Ludema, "Surface damage of structural ceramics: implications for wear modeling", Wear 124 (1988) 237-257.

[53] P. Švančárek, S. Lendvayová, D. Galusek, M. Hnatko, I. Vávra, X. Wang, "Abrasive wear resistance of $\mathrm{SiO}_{2}$-doped polycrystalline alumina", Wear 271 (2011) 760-769.

[54] W. D. Callister, Ciência e engenharia de materiais: Uma introdução [Materials science and engineering: an introduction], $7^{\text {a }}$ Ed. Rio de Janeiro, RJ, Brazil, LTC Ed. (2008) $705 \mathrm{p}$.

[55] M. M. Seabaugh, I. H. Kerscht, G. L. Messing, “Texture development by templated grain growth in liquid-phasesintered-alumina" J. Am. Ceram. Soc., 80, 5 (1997) 11811188.

[56] F. Bouville, E. Maire, S. Meille, B. V. Moortèle, A. J. Stevenson, S. Deville, "Strong, tough and stiff bioinspired ceramics from brittle constituents", Nature Mater. (2014) 1-7.

[57] J. A. Salem, J. L. Shannon, R. C. Bradt, "Crack growth resistance of textured alumina", J. Am. Ceram. Soc. 72, 1 (1989) 20-27.

[58] T. Carisey, I. Levin, D. G. Brandon, "Microstructure and mechanical properties of textured $\mathrm{Al}_{2} \mathrm{O}_{3,,}$ J. Eur. Ceram. Soc. 15 (1995) 283-289.

[59] F. F. Lange, "Sinterability of agglomerated powders", J. Am. Ceram. Soc. 67, 2 (1984) 83-89.

[60] A. Krell, P. Blank, "Grain size dependence of hardness in dense submicrometer alumina", J. Am. Ceram. Soc. 78, 4 (1995) 1118-1120.

[61] J. K. Montgomery, P. L. Drzal, K. R. Shull, K. T. Faber,
"Thermoreversible gelcasting: a novel ceramic processing technique", J. Am. Ceram. Soc. 85, 5 (2002) 1164-1168.

[62] S. Kitaoka, Y. Yamaguchi, Y. Takahashi, "Tribological characteristics of $\alpha$-alumina in high-temperature water", J. Am. Ceram. Soc. 75, 11 (1992) 3075-3080.

[63] A. P. Goswami, S. Roy, M. K. Mitra, G. C. Das, "Microstructure-dependent hardness and fracture behavior in liquid-phase-sintered $\mathrm{Al}_{2} \mathrm{O}_{3}$ ”, Ceram. Int. 26 (2000) 397 410.

[64] D. B. Marshall, B. R. Lawn, R. F. Cook, "Microstructural effects on grinding of alumina and glass-ceramics", J. Am. Ceram. Soc. 70, 6 (1987) 139-140.

[65] A. P. Goswami, S. Roy, "Impurity-dependent morphology and grain growth in liquid-phase-sintered alumina", J. Am. Ceram. Soc. 84, 7 (2001) 1620-1626.

[66] P. Chantikul, S.J. Bennison, B.R. Lawn, "Role of grain size in the strength and R-curve properties of alumina", J. Am. Ceram. Soc. 73, 8 (1990) 2419-2427.

[67] I. M. Peterson, T.-Y. Tien, "Effect of the grain boundary thermal expansion coefficient on the fracture toughness in silicon nitride", J. Am. Ceram. Soc. 78, 9 (1995) 2345-2352. [68] P. F. Becher, E. Y. Sun, K.P. Plucknett, K. B. Alexander, C. -H. Hsueh, H. -T. Lin, S. B. Waters, C. G. Westmoreland, "Microstructural design of silicon nitride with improved fracture toughness: I, effects of grain shape and size", J. Am. Ceram. Soc. 81, 11 (1998) 2821-2830.

[69] M. Terheci, "Grain boundary and testing procedure: a new approach to the tribology of alumina materials", Wear, 211 (1997) 289-301.

[70] G. K. L. Goh, L. C. Lim, M. Rahman, S. C. Lim, "Effect of grain size on wear behaviour of alumina cutting tools", Wear 206 (1997) 24-32.

[71] R. Apetz, M. P. M Van Bruggen, "Transparent alumina: a light-scattering model”, J. Am. Ceram. Soc. 86, 3 (2003) 480-86.

[72] A. Krell, "Improved hardness and hierarchic influences on wear in submicron sintered alumina", Mater. Sci. Eng. A 209 (1996) 156-163.

[73] A. Krell, P. Blank, "The influence of shaping method on the grain size dependence of strength in dense submicrometre alumina", J. Eur. Ceram. Soc. 16 (1996) 1189-1200.

[74] S. Yip, "The strongest size", Nature 391 (1998) 532533.

[75] A. Krell, "A new look at the influences of load, grain size, and grain boundaries on the room temperature hardness of ceramics", Int. J. Refract. Met. Hard Mater. 16 (1998) 331-335.

[76] A. Krell, S. Schädlich, "Nanoindentation hardness of submicrometer alumina ceramics", Mater. Sci. Eng., A 307 (2001) 172-181.

[77] G. Magnania, A. Brillante, "Effect of the composition and sintering process on mechanical properties and residual stresses in zirconia-alumina composites", J. Eur. Ceram. Soc. 25 (2005) 3383-3392.

[78] H. H. Luo, F. C. Zhang, S. G. Roberts, "Wear resistance of reaction sintered alumina/mullite composite", Mater. Sci. Eng. A 478 (2008) 270-275. 
[79] B.-N. Kim, S. Wakayama, M. Kawahara, "Characterization of 2-dimensional crack propagation behavior by simulation and analysis", Int. J. Fracture. 75 (1996) 247-259.

[80] N. A. Yahyaa, R. I. Todd, "Influence of C doping on the fracture mode and abrasive wear of $\mathrm{Al}_{2} \mathrm{O}_{3}$ ", J. Eur. Ceram. Soc. 32 (2012) 4003-4007.

[81] J. L. Ortiz-Merino, R. I. Todd, "Relationship between wear rate, surface pull out and microstructure during abrasive wear of alumina and alumina/SiC nanocomposites", Acta Mater. 53 (2005) 3345-3357.

[82] A. Limpichaipanit, R. I. Todd, "The relationship between microstructure, fracture and abrasive wear in $\mathrm{Al}_{2} \mathrm{O}_{3} /$ $\mathrm{SiC}$ nanocomposites and microcomposites containing 5 and 10\% SiC", J. Eur. Ceram. Soc. 29 (2009) 2841-2848.

[83] H. J. Chen, W. M. Rainfort, W. E. Lee, "The wear behaviour of $\mathrm{Al}_{2} \mathrm{O}_{3}-\mathrm{SiC}$ ceramic nanocomposites", Scripta Mater. 42 (2000) 555-560.

(Rec. 02/09/2014, Rev. 22/12/2014, Ac. 22/12/2014) 